\title{
Protein aggregates carry non-genetic memory in bacteria after stresses
}

\author{
O. Ye. Kukharenko ${ }^{1}$, V. O. Terzova ${ }^{1,2}$, G. V. Zubova ${ }^{1}$ \\ ${ }^{1}$ Institute of Molecular Biology and Genetics, NAS of Ukraine \\ 150, Akademika Zabolotnoho Str., Kyiv, Ukraine, 03143 \\ 2 National University of "Kyiv-Mohyla Academy" \\ 2, Skovorody Str., Kyiv, Ukraine, 04655 \\ hikia48@gmail.com
}

Protein aggregation is related to the formation of oligomers and aggregates, leading to impaired cellular processes. The protein aggregates formation is associated with pathologies and ageing in eukaryotes whereas in bacteria aggregation causes dramatic changes in growth rate, stress resistance and virulence, and eventually these aggregates play a functional role. Both cellular and environmental factors enhance protein damage via aggregation, nonetheless, upon sublethal doses of proteotoxic environmental stressors, protein aggregates may improve cellular robustness and carry a type of non-genetic memory of the previous stressors through several generations. Emerging data on aggregated proteins, carrying non-genetic (epigenetic) traits, show that protein-based inheritance is known within all three kingdoms of living organisms. This review focuses on the protein aggregates as carriers of non-genetic memory in bacteria.

Keyw or d s: bacteria, protein aggregates, stress, epigenetics.

\section{Introduction}

Epigenetics studies on the non-genetic heritable alterations, i.e those, which do not arise from altered DNA sequence, but from its gene expression [1]. The most common types of epigenetic modification are DNA methylation, histone modification and nucleosome positioning [2-4]; often the epigenetic changes are mediated by small non-coding RNAs [5]. Separate forms of molecular memory are not linked to the changes in chromatine and are connected with individual or collective activi- ty of proteins such as prions [6] and chaperone molecules $[7,8]$. Prions are able to self-template over long biological timescales (well reviewed in [9]). It has recently become known that prions can play a role of the molecular memory carriers in bacteria [10-12]. As the prions are heritable, the findings suggest that these proteins could allow bacteria to inherit the traits without the need for genetic mutation. In addition to the classical prion-based epigenetic memory, other types of protein-based in-

(C) 2020 O. Ye. Kukharenko et al:; Published by the Institute of Molecular Biology and Genetics, NAS of Ukraine on behalf of Biopolymers and Cell. This is an Open Access article distributed under the terms of the Creative Commons Attribution License (http://creativecommons.org/licenses/by/4.0/), which permits unrestricted reuse, distribution, and reproduction in any medium, provided the original work is properly cited 
herited memory have also been reported. Most of them do not meet the definition of prions (proteinaceous and infectious), but nevertheless they are the carriers of timescale memory. Among them, the most known type of proteinbased inherited memory is the protein aggregates (PAs) such as $\mathrm{A} \beta$-amyloid in Alzheimer's disease and $a$-synuclein in Parkinson's disease [13], as well as the curli fibres, contributing to scaffold biofilms in bacteria [14]. In contrast to prions, PAs are not self-proliferative; they presumably consist of a multitude of different protein species. Here, their role as the elements of microbial inherited adaptability in stress responses will be highlighted.

\section{Protein aggregates are formed in bacteria under normality and stresses}

Protein aggregates disturb proteostatic balance in cells. Proteins are central components of almost all biological processes. The transformation of a linear amino acid structure into properly composed structures is the principle of protein biogenesis. After the synthesis of a polypeptide in ribosome, the protein chain immediately undergoes folding into $\alpha$-helical and $\beta$-strand secondary structure elements. To achieve their functional state, most newly synthesized proteins fold into specific three-dimensional structures and sometimes further assemble into multimeric protein complexes. Protein folding depends on a network of noncovalent interactions, involving both the polypeptide's backbone and amino acid side chains. Although many proteins are assembled autonomously, many of them require the assistance of molecular chaperones [15].

During the folding process, the formation of misfolded protein species naturally occurs, and these failures may be enhanced by both intrinsic and extrinsic stressors. Moreover, proteins can unfold, producing disordered polypeptides that lack secondary or tertiary structure. Hydrophobic interactions between exposed residues or intermolecular $\beta$-sheet formation lead to the protein aggregation (reviewed in $[15,16])$. Unreasonable unfolding of native proteins, as well as interference of un- and misfolded proteins with partially folded species, can create a functional deficit, which impairs essential cellular processes, and may lead to the cell death. Therefore, living organisms rely on protein quality control systems to prevent and reverse accumulation of un- and misfolded proteins.

Cellular strategies of protein aggregation control, such as gate-keeping residues, limiting hydrophobicity and exposure of aggregationprone regions, reduce transcription and translation rates, protein abundance and rapid degradation of proteins [16]. In humans, more than 800 genes are involved in proteostasis control [17]. All these actions in bacteria assist to molecular chaperones and proteases that refold or degrade un- and misfolded proteins in order to maintain proteostasis $[18,19]$. Chaperones are involved in the disaggregation of aggregated proteins, and their number is directly related to the quality of the disaggregation [19-21]. In particular, it is indicated for the chaperone Hsp104, which carries out the fragmentation of protein aggregates [21]. The factors that determine the frequency of fragmentation are still unclear, however, the important role of amino acids and other substances has been established: long polyglutamine stretches have been shown to be markers of poorly fragmented PA formation. In fact, $20-30 \%$ of prokary- 
otic cytoplasmic proteins pass through DnaK or GroEL chaperones during proteogenesis [15]. These mechanisms involve not only a control system of chaperones and proteases, but also genetic and evolutionary strategies to reduce aggregation, when it is inappropriate. Moreover, the aggregation-prone proteins are under strict transcriptional, translational and degradation control to ensure that the levels of these proteins are low. Intracellular misfolded protein assemblies control regulation of gene expression by small RNAs, transcription termination and plasmid DNA replication in bacteria [22]. Additionally, the aggregation-prone regions are protected from interactions within the core of the protein. Failure of these strategies can disturb the proteostatic balance and lead to the decrease of cell viability or its death.

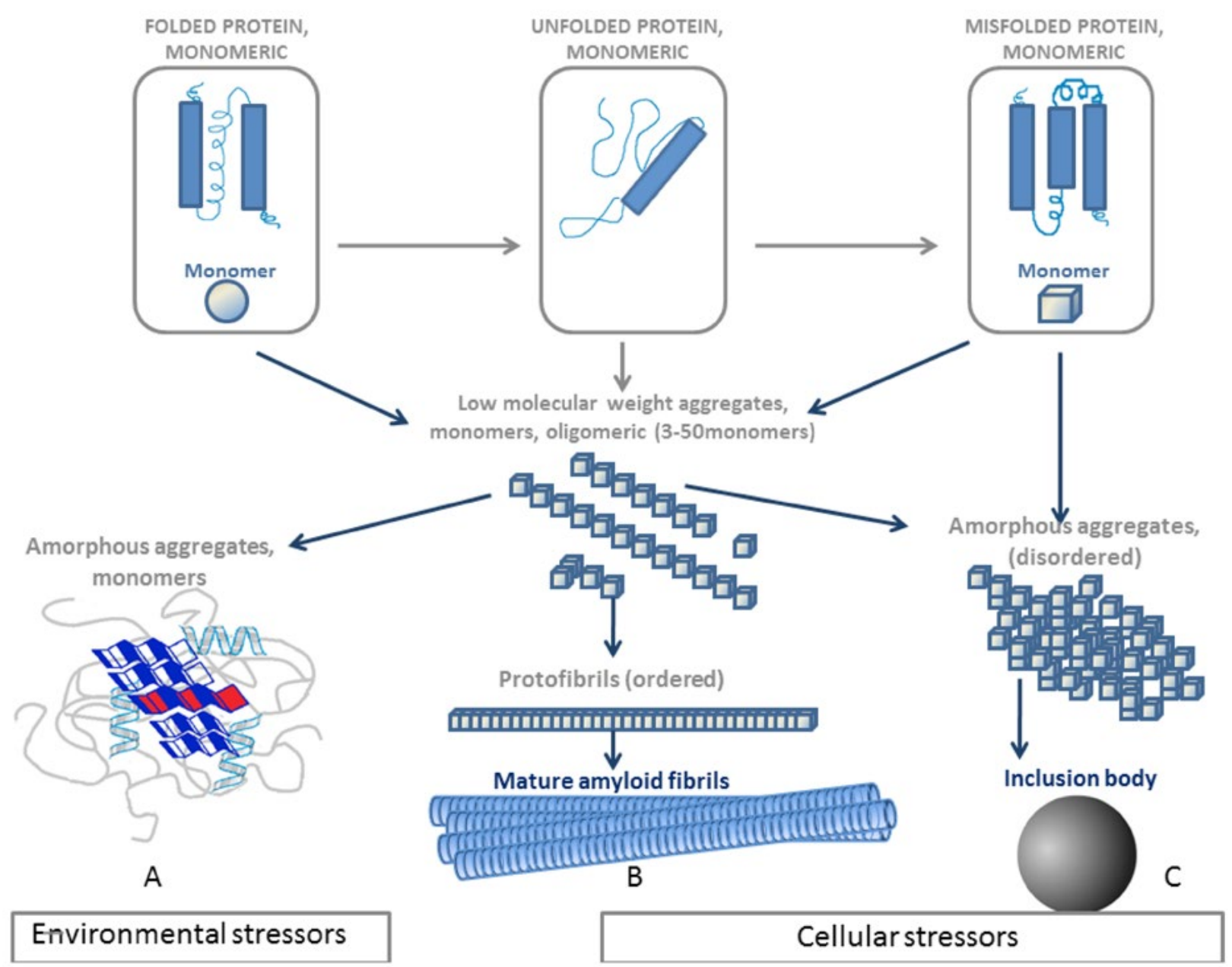

Fig. 1. Protein aggregation results in the formation of amorphous aggregates (A), amyloid fibrils (B) and inclusion bodies (C). In bacteria, type of aggregates depends on a variety of stressors and it is mainly amorphous formation, however, under heterologous expression bacteria form amyloid fibrils. 
The types of protein aggregates. PAs are different and divided into several classes, exhibiting different size, reversibility/dissociation, spatial structure of the molecule (conformation), covalent modification and morphology [22, 23]. Protein aggregates can be classified into two general categories: amorphous and amyloid. Amorphous protein aggregates are mostly monomers. This type of aggregation can be best described as the apparently unordered aggregation of proteins, not generally associated with disease when aggregated. The bacterial protein amorphous aggregates are caused mainly by environmental stressors. Co-aggregation of proteins results in the formation of globular amorphous aggregates through nonspecific hydrophobic interactions, and to a lesser extent through sequence-specific $\beta$-strand interactions [19, 24].

The oligomers or so-called amyloids consist of several protein aggregates-monomers and may exist as amyloid fibril or inclusion body (Fig. 1B, C). The amyloid state is a highly structured, insoluble, fibrillar deposit with a unique quaternary structure comprised of extended $\beta$-sheets formed from intermolecular hydrogen bonding, usually consisting of many repeats of the same protein $[18,19,22]$. The constituent $\beta$-strands of the $\beta$-sheets run perpendicular to the axis of the fibril, resulting in a conformation known as the 'cross- $\beta$-sheet' [25]. This type of aggregation is central in the pathology of many neurodegenerative diseases including Alzheimer's, Parkinson's and Huntington's diseases [13]. By contrast, protein deposition in bacteria occurs in the form of inclusion bodies regarded as amorphous aggregates [26]. Nonetheless, bacterial amyloid proteins display the physiochemical char- acteristics similar to other amyloids [27]. These include binding to thioflavin $\mathrm{T}$ and Congo Red dyes with resultant increased fluorescence emission at $485 \mathrm{~nm}$ and green birefringence, respectively, fibril-like morphology and a $\beta$-sheet rich structure as demonstrated by biophysical investigations [25].

In bacteria, protein aggregates have subcellular localization. Fluorescence microscopy techniques and cryo-tomography are employed to investigate PA formation and resolution in individual cells, which can provide intriguing information on the location, movement and resolution over the lifespan of individual cells [28]. Fluorescently tagged endogenous small heat shock proteins have frequently been used as aggregate reporters in $E$. coli, as they are highly upregulated in response to proteotoxic stress and are abundantly incorporated into aggregates [29]. It was discovered that in E.coli, PAs are formed at the poles in response to many different stresses, as well as at midcell in predivisional cells [30]. A more numerous and distributed pattern of protein aggregation localization has been demonstrated in both Mycobacteria and Caulobacter crescentus. In C. crescentus, protein aggregation also occurs in multiple punctate foci that are distributed throughout the entire cell volume in response to heat and antibiotic stress [28]. However, whereas the aggregates of Mycobacteria continue to move after formation, those of $C$. crescentusare are mostly stationary [28]. Large E. coli PAs were observed to segregate asymmetrically and were inherited after division to one of two emerging daughter cells [29, 31] (Fig. 2). Govers et al. [29] induced PAs in E. coli by exposing the cells to heat and, using validated fluorescent 
PA reporters, showed that when the given bacterial cell subsequently divided, the PAs were segregated into only one of the two daughter cells (Fig. 2A). A new pattern of protein aggregate inheritance was found in a free-living aquatic bacterium C.crescentus [32]. It is interesting to note that, in contrast to the deposition of PAs at the pole in E. coli and Mycobacterium tuberculosis [33] and their asymmetric distribution between daughter cells, in $C$. crescentus, the bacterium with asymmetric cell division and DNA replication only once per cell cycle, the PAs, formed under the impact of either heat or antibiotics, were distributed to both daughter cell types at the same ratio over successive divisions (Fig. 2B).

Protein aggregation is provoked by extrinsic and intrinsic stressors and results in disturbance of bacterial proteostasis. Protein aggregation, which the cell cannot quickly eliminate with its own repairing chaperone proteins, occurs due to the disruption of protein homeostasis as a response to stressors. That is quite common for all living entities. For prokaryotes, this issue is insufficiently covered. Protein homeostasis of various model and extremophilic species of bacteria (E. coli, C. crescentus, Clostridium botulinum, Acinetobacter baumannii etc) is currently being actively studied $[10,26-30,34]$. The emerging data on the study of these model bacteria show that accumulation of PAs is directly related to the impact of stressors and population "ageing". Increased protein aggregation is provoked by a heat shock, action of antibiotics (aminoglycosides) and antimicrobial peptides, depletion of the nutrient medium, oxidized stress, heavy metals, ultraviolet light, hydrostatic pressure, ionic strength, $\mathrm{pH}$ [24, 32, 34-36]. Below we provide few examples documenting the impact of environmental stressors on PAs formation in bacteria. High pressure $(>100 \mathrm{MPa})$ causes a significant dispersion of PAs in the cytoplasm of the cell, increasing the lethality and susceptibility of the culture to other minor stresses. In contrast, weak pressure $(\leq 100 \mathrm{MPa})$ does

B

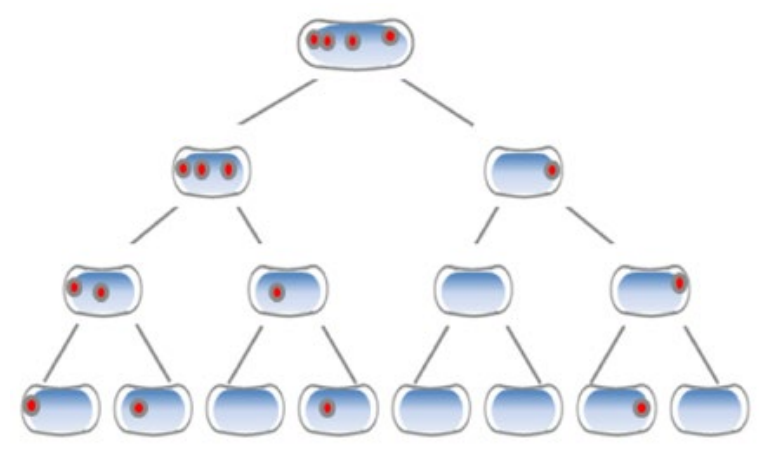

- protein aggregate free cells

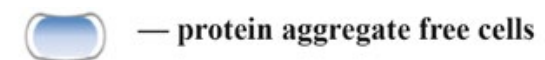

- - protein aggregate

— protein aggregate free cells

Fig. 2. Different mode of Protein Aggregate (PA) location and distribution among progenitor cells during timescale. A, the PAs are located subcellularly at a pole and are distributed asymmetrically within the bacterial population. B, the PAs form distributed foci throughout the length of the cell. Aggregates are constantly distributed between old and new pole cells. 
not provoke strong dispersion and lethality of the population $[35,36]$. Sublethal concentrations of aminoglycoside antibiotics such as kanamycin and streptomycin cause mRNA mistranslation, resulting in the creation of folding-deficient protein species, which can induce aggregation [28].

The toxic metalloid arsenite promotes protein aggregation in yeast culture by interfering with the folding of nascent polypeptides and by chaperone inhibition [24]. Two another stressors - azetidine-2-carboxylic acid (AZC) and hydrogen peroxide $\left(\mathrm{H}_{2} \mathrm{O}_{2}\right)$ - promote misfolding and aggregation through different mechanisms, i.e., AZC as proline analog, incorporates competitively into proteins and alters the conformation of the polypeptide backbone, resulting in widespread protein misfolding and aggregation; $\mathrm{H}_{2} \mathrm{O}_{2}$ gives rise to oxidative stress in cells, which may in turn damage proteins and promote their aggregation. The stress conditions described above, work by distinct mechanisms, promoting the aggregation of similar types of proteins, probably by lowering the threshold of protein aggregation. This may suggest that the proteins in aggregates are intrinsically aggregationprone, rather than the proteins which are affected in a stress-specific manner [24].

Under a moderate stress, PAs are short-lived and rapidly eliminated by the chaperone DnaK and the disaggregase ClpB. Severe stressors or genetic perturbation of the protein quality control machinery induce the formation of long-lived aggregates[28].

Noteworthy, intracellular cues induce PAs formation in bacteria. Heterologous protein expression in bacteria can result in the formation of amyloid fibrils and inclusion bodies (see Fig. 1B,C). In heterologous overexpression used for protein production, a highly abundant protein can aggregate into globular inclusion bodies containing both amyloid and natively folded protein structures [19]. It is known for $E$. coli that even under stress-free conditions about $20 \%$ of the synthesized proteins never reach the natural conformation. Unproper protein conformations result from various errors during the gene transcription, translation and protein folding steps. Certain proteins may aggregate post-translationally due to an imbalance between its abundance and solubility [24]. Together, all these studies suggest that protein aggregation is a normal physiological process highly subjected to perturbations in cellular homeostasis which can increase the burden of protein aggregation. The establishment of non-functional protein-protein interactions has a detrimental impact on the cell fitness because these bindings sequester proteins into inactive complexes leading to aggregation or co-aggregation of proteins into toxic soluble or insoluble assemblages [37]. Moreover, the accumulation of damaged proteins is a hallmark of ageing, occurring in the organisms ranging from bacteria and yeast to mammalian cells [38].

Protein aggregates are toxic and can damage cellular membrane. Stressful factors affect bacterial proteogenesis directly or indirectly. Thus, numerous proteins, being aggregated into amyloids, damage bacterial membranes. As previously stated, the formation of amyloids involves misfolding of soluble proteins into $\beta$-sheet oligomers, which further aggregate into protofibrils, including ring-like annular protofibrils, and then into amyloid fibrils [39] as illustrated in Fig. 3A. 


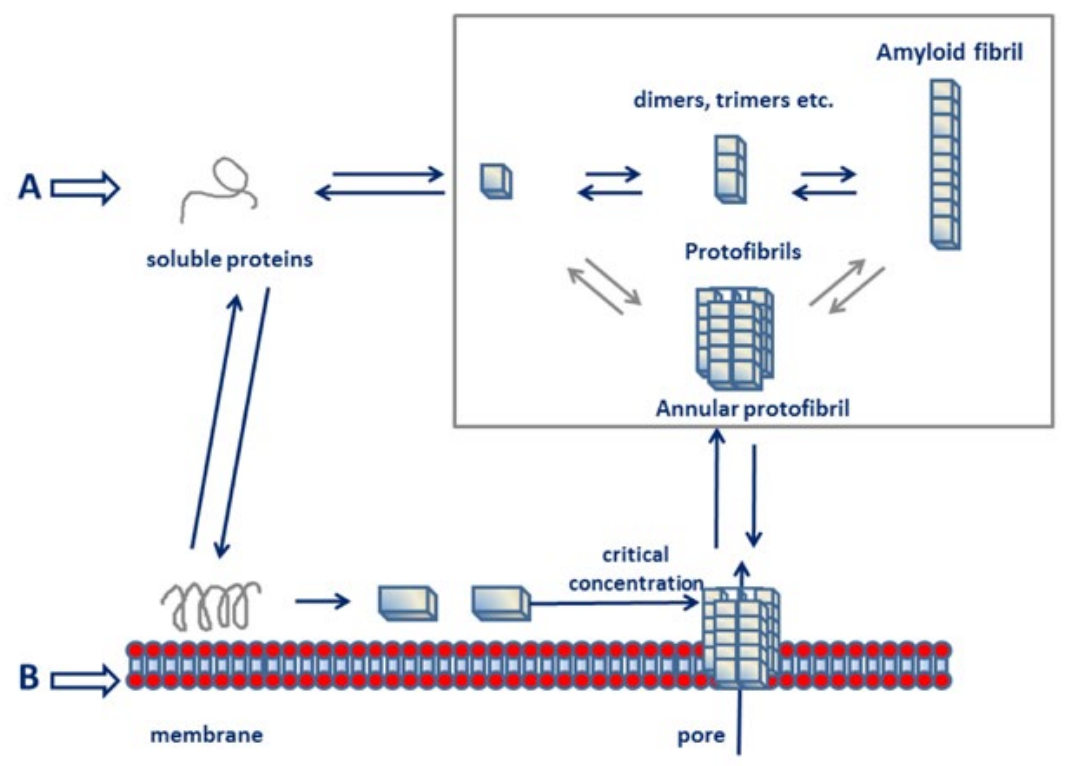

Fig. 3. Interconnectivity between amyloid formation and membrane disruption. A, the process of amyloid fibril formation. B, the pore formation by amyloid fibrils and the role of membranes in amyloid formation and toxicity [39].

The amyloid formation affects bacterial membrane and confers on its toxicity (Fig. 3B). Soluble proteins bind to membrane surfaces predominantly to ana-helix structure. The accumulation of proteins on the membrane surface induces oligomerization of proteins into sheet aggregates. When a critical threshold concentration is reached, a transmembrane pore develops in the membrane, which enables leakage of the membrane contents. Annular protofibrils may be formed in solution by other or coexistent mechanisms, e.g., by binding to the membrane surface and inducing membrane thinning; lipids may be extracted from the membrane and incorporated into the developing fibril in a detergent-like process [39].

Notably, bacterial functional amyloids, which act as scaffold fibrils for biofilms, can damage membranes of the producing bacteria, when fibrils move outside. Normally, eukaryotic amyloid fibrils have a well-ordered structure that is not damaged while interacting with the eukaryotic cell membrane. On the contrary, prokaryotic amyloid proteins have a chaotically ordered structure, and the prokaryotic membrane undergoes significant damage, when interacts with these proteins. This proves that eukaryotic membranes are much more resistant to the interaction with amyloids than bacterial ones [40].

In the in vitro and in vivo studies on $E$. coli, the effect of synthetic protein $\operatorname{Rep} A-W H 1$ (that causes the development of amyloid proteinopathy and inhibits the growth of bacterial culture) resulted in the pore formation, compromised membrane integrity and disrupted bioenergetics. The authors substantiated this phenomenon by the ability of $\operatorname{RepA}-W H 1$ to disrupt the cell membrane and form the pores in it, which violated the integrity of the cell and led to death $[41,42]$.

In the last two decades, functional amyloids have been found in almost all biological systems from viruses to humans and were sug- 
gested as putative ancient mechanisms of protein functioning [25].

In spite of their putative harmfulness, some amyloids fulfill essential functions in bacteria. Multiple bacterial functional amyloids have been identified as those that can contribute to adhesion, biofilm development, genetic competence, cell density regulation, host interactions, etc. (reviewed in [25, 43]). The microbial amyloid formation is generally recognized as a biofilm-associated process. It is already known that amyloids are synthesized in the cytosol of a bacterial cell and are maintained as monomers within the periplasm until secretion, which occurs through membrane permeases [44]. Proteins that assemble into amyloid can serve as scaffolds to increase stiffness and unify the extracellular matrix and cells within biofilms. The amyloid moiety formed outside of the cells may serve as an adherence factor, contributing to the biofilm formation as it was demonstrated on Pseudomonas spp. [45] and Staphylococcus epidermidis [46]. The robust amyloid proteins are also important for the biofilm structuring in Streptococcus mutans [47], Bacillus subtilis [48] and Staphylococcus aureus [49].

Functional amyloids also confer adhesive properties independently of bacterial biofilms. The presence of bacterial amyloids can be advantageous for colonization, persistence and spread of bacterial pathogens, as they can serve as virulence factors. The mechanism of M. tuberculosis pathogenicity is the use of polymeric pili on their outer cellular surface [50]. Pili located on the surface of individual mycobacterial cell have similar morphology and functionality to the curli fibers; however, the underlying sequences of pili are distinct from both fap and curli amyloid systems [50]. Aggregation was shown to be the mechanism of pathogenicity for many bacterial toxins, e.g., aerolysin, the toxin responsible for pathogenicity of Aeromonas hydrophila. Aerolysin first aggregates with the erythrocyte protein glycophorin and follows an oligomerization step before being able to disrupt the erythrocyte membrane. Another bacterial toxin, parasporin, produced by Bacillus thuringiensis, shows a homology with aerolysin and similarly aggregates into oligomers on the plasma membrane of mammalian cells [18]. In the plant pathogenic bacterium Xanthomonas, harpins, i.e. proteins secreted by type III secretion systems, cause a hypersensitive response in plants at the conversion from a soluble state to amyloid [51]. In a recent study, an interkingdom interaction of bacterial amyloidogenic subunit of curli fibers (CsgA), produced by E. coli, and murine $\alpha$ Syn revealed the amyloid aggregation and inflammation in the murine gut and brain [52]. In another study, in vivo and in vitro experiments have evidenced that the functional microbial amyloid proteins produced in the gut may cross-seed $\mathrm{A} \beta$ aggregation and prime the innate immune system to have an enhanced pathogenic response to neuronal amyloids [53].

Protein aggregates may provide a protective repository for proteins during stresses An improper coagulation and aggregation of proteins under the impact of various stressors are usually perceived as inevitable and destructive processes associated with a disruption of the cellular proteostasis; nonetheless, at sublethal doses this process is rather useful for the adaptability [29, 34]. In bacteria, the stressors do 
not completely suppress the vital activity. It has been found that the aggregation of specific proteins under certain conditions can regulate the expression of certain genes and proper distribution of cellular resources that is one of the means of cellular self-regulation under adverse conditions [20, 22]. In particular, the researchers found that the increase in cellular PAs, which was considered harmful, helped the bacteria A.baumannii to survive desiccation. PAs might protect some of the A. baumannii proteome from damage during desiccation and provide functional proteins for recovery during rehydration [34].

Sublethal proteotoxic stressors, such as heat, peroxide and the antibiotic (e.g., streptomycin, kanamycin) cause PA formation, which plays special role in the acquisition of epigenetic memory on previous insults and helps to overcome their consequences as well as other insults in the future $[29,54]$.

\section{Protein aggregates as carriers of molecular memory in bacteria}

Protein aggregates as molecular remnants from previous environmental insults. Stressors trigger the formation of PAs and population heterogeneity. To cope with environmental stressors, living organisms use the single-cell and population-level reparation mechanisms. The difference in growth rate between emerging subpopulations creates the fitness variation that increases the efficiency of natural selection for eliminating the damage from the population. The persistent large PAs can be stored as the remnants of past stresses mainly at one of the poles of the bacterial cell and thus only one of daughter cells will inherit it. The asymmetric damage segregation increases the reproduc- tive rate and survival of cellular populations under the conditions when the efficiency of repair is low compared to the rate of damage accumulation [33]. The distribution of asymmetric damaged molecules is typical for the species of bacteria that reproduce by morphologically symmetrical division. In the study by Govers et al. [29], E. coli cells with induced PAs were again exposed to the aggregate-inducing stressor after multiple generations. The cells containing inherited aggregates displayed an improved survival and faster recovery than those without the aggregates, leading to an enrichment of their progeny in the emerging population. The ancestral PAs also provided bacteria with resilience to other proteotoxic stressors, such as peroxide, which caused the formation of reactive oxygen species, and antibiotics; on the contrary, the isogenic PA-free cell lines were sensitive to those stressors. The authors found that the PA-bearing cells inherited more protective proteins against stressors and suggested this fact as an explanation of the increased cell survival. The PAs thus served as a kind of inherited memory that protects the progeny against the challenges experienced by their ancestors. It is currently hypothesized that PA-mediated memory is accomplished by a specific enrichment of protein quality control elements (such as DnaK, DnaJ, ClpB, IbpA, and ClpP) due to co-localization and co-inheritance with the PAs [29]. This enrichment might in turn be responsible for the increased robustness of PA-bearing cells toward proteotoxic stressors. This new paradigm proposed by Govers et al. [29] suggests that other types of cytoplasmically inheritable damaged but functional biomolecules could also serve for improvement of the cellular robustness within 
a timescale. In the mentioned above study [34], PAs were shown to protect $A$. baumannii from the desiccation collapse by preserving the functional proteins within aggregates.

Inheritable prion-like proteins in bacteria play a functional role and can be horizontally trasmitted. Recently, in bacterial proteomes, more than 2000 potential bacterial prions with different functional roles have been discovered using the prion prediction algorithm $[55,56]$. For example, the bacteriotoxin microcin E492, an antibiotic produced by Klebsiella pneumoniae only during the exponential phase of growth, acquires a prion-like form and therefore loses the activity to kill competitors in the stationary phase due to a conversion of the soluble protein into insoluble fibrils [57]. In two other bacterial proteins, Rho and Rep A, [the] domains responsible for the prion-like phenotype have been proven [10, 42]. In particular, it was found that transcription terminator Rho of C. botulinum (CbRho) can transform into a prion due to the presence of the prion-forming domain, which is responsible for the acquired amyloidogenicity. The soluble form of this protein efficiently terminates transcription, whereas in the self-propagating aggregated prion form it was functionally compromised [10]. The CbRho is the determinant of an epigenetically transmissible phenotype, structurally and functionally analogous to yeast prions [58] and can functionally replace Sup35 prionogenic sequences in a stop-codon read-through translation assay in yeast. The Rho prion-like domain family is one of three most widely distributed prion-like protein domain families [12]. The RepA is another bacterial protein that builds intracellular amyloid oligomers acting as an inhibi- tory complex of plasmid DNA replication. A mutation in the N-terminal domain (WH1) of this protein, enhancing its amyloidogenesis, generates inheritable cytosolic amyloid particles. With this mutation, RepA-WH1 becomes cytotoxic in E. coli and meets all the criteria to qualify it as a prion-like protein [20]. Protein aggregates are cell-to-cell transmissible through either tunneling nanotubes or extracellular vesicles $[20,59]$. Horizontal transmissibility of RepA-WH1 from the bacteria to the murine and human neuroblastoma cell lines has been demonstrated, as well as the formation of cytotoxic amyloid particles in the recipient cells [20].

\section{Conclusion}

Due to phenotypic heterogeneity endowed after an impact of cellular or environmental stressors, certain subpopulations of bacteria acquire an epigenetic memory of the stresses due to the formation of inheritable protein aggregates. Intracellular PAs essentially lack a self-proliferative effect, however, remain inheritable for many generations due to the asymmetric segregation and limited disaggregation that prevents their dilution. Such change in protein homeostasis helps to overcome more quickly similar stresses encountered in future in many subsequent generations of bacterial cultures. Epigenetic memory is formed and maintained even after the processes of protein disaggregation. Inherited PAs increase the resistance of bacteria to a wide range of other emerging proteotoxic stressors. Prokaryotic PA-mediated memory seems to comprise a completely novel type of protein-based inheritance, and this phenomenon requires further study. 


\section{REFERENCES}

1. Danchin E, Wagner RH. Inclusive heritability: combining genetic and nongenetic information to study animal behavior and culture. Oikos.2010; 119(2): 210-18.

2. Holliday R, Pugh JE. DNA modification mechanisms and gene activity during development. Science. 1975;187(4173):226-32.

3. Nanney $D L$. Epigenetic control systems. Proc Natl Acad Sci U S A. 1958;44(7):712-7.

4. Riggs $A D$. X inactivation, differentiation, and DNA methylation. Cytogenet Cell Genet. 1975;14(1):9-25.

5. Duempelmann L, Skribbe M, Bühler M. Small RNAs in the Transgenerational Inheritance of Epigenetic Information. Trends Genet. 2020;36(3):203-214.

6. Harvey ZH, Chakravarty AK, Futia RA, Jarosz DF. A Prion Epigenetic Switch Establishes an Active Chromatin State. Cell. 2020;180(5):928-940.e14.

7. Lindquist $S$. Lamarck redux: prions, Hsp90, and the inheritance of environmentally acquired traits. In: Molecular Frontiers Symposium 2011: Origin of Life and Molecular Evolution. 24 May 2011.

8. Hammond CM, Strømme CB, Huang H, Patel DJ, Groth A. Histone chaperone networks shaping chromatin function. Nat Rev Mol Cell Biol. 2017; 18(3):141-158.

9. Harvey $Z H$, Chen $Y$, Jarosz DF. Protein-Based Inheritance: Epigenetics beyond the Chromosome. Mol Cell. 2018;69(2):195-202.

10. Yuan AH, Hochschild A. A bacterial global regulator forms a prion. Science. 2017;355(6321):198-201.

11. Fleming E, Yuan AH, Heller DM, Hochschild A. A bacteria-based genetic assay detects prion formation. Proc Natl Acad Sci U S A. 2019;116(10): 4605-10.

12. Harrison PM. Evolutionary behaviour of bacterial prion-like proteins. PLoS One. 2019;14(3):e0213030.

13. Jucker M, Walker LC. Self-propagation of pathogenic protein aggregates in neurodegenerative diseases. Nature. 2013;501(7465):45-51.

14. Ageorges V, Monteiro R, Leroy S, Burgess CM, Pizza M, Chaucheyras-Durand F, Desvaux M. Molecular determinants of surface colonisation in diar- rhoeagenic Escherichia coli (DEC): from bacterial adhesion to biofilm formation. FEMS Microbiol Rev. 2020;44(3):314-350.

15. Wang $W$, Roberts $C J$. Protein aggregation - Mechanisms, detection, and control. Int $J$ Pharm. 2018;550(1-2):251-268.

16. Tyedmers J, Mogk A, Bukau B. Cellular strategies for controlling protein aggregation. Nat Rev Mol Cell Biol. 2010;11(11):777-88.

17. Cox D, Raeburn C, Sui X, Hatters DM. Protein aggregation in cell biology: An aggregomics perspective of health and disease. Semin Cell Dev Biol. 2020;99:40-54.

18. Bednarska NG, Schymkowitz J, Rousseau F, Van Eldere J. Protein aggregation in bacteria: the thin boundary between functionality and toxicity. Microbiology (Reading). 2013;159(Pt 9):17951806.

19. Schramm FD, Schroeder K, Jonas K. Protein aggregation in bacteria. FEMS Microbiol Rev. 2020;44(1):54-72.

20. Revilla-García A, Fernández C, Moreno-Del Álamo M, de Los Ríos V, Vorberg IM, Giraldo R. Intercellular Transmission of a Synthetic Bacterial Cytotoxic Prion-Like Protein in Mammalian Cells. mBio. 2020;11(2):e02937-19.

21. Alexandrov AI, Polyanskaya AB, Serpionov GV, Ter-Avanesyan MD, Kushnirov $V V$. The effects of amino acid composition of glutamine-rich domains on amyloid formation and fragmentation. PLoS One. 2012;7(10):e46458.

22. Marcoleta A, Wien F, ArluisonV, Lagos R, Giraldo R. Bacterial Amyloids. eLS. John Wiley \& Sons Ltd: Chiche-ster, 2019.

23. Narhi LO, Schmit J, Bechtold-Peters K, Sharma D. Classification of protein aggregates. $J$ Pharm Sci. 2012;101(2):493-8.

24. Weids AJ, Ibstedt S, Tamás MJ, Grant CM. Distinct stress conditions result in aggregation of proteins with similar properties. Sci Rep. 2016;6: 24554.

25. Shanmugam N, Baker MODG, Ball SR, Steain M, Pham CLL, Sunde M. Microbial functional amyloids serve diverse purposes for structure, adhesion and defence. Biophys Rev. 2019;11(3):287-302. 
26. Bowden GA, Paredes AM, Georgiou G. Structure and morphology of protein inclusion bodies in Escherichia coli. Biotechnology (N Y). 1991;9(8):725-30.

27. Chapman MR, Robinson LS, Pinkner JS, Roth R, Heuser J, Hammar M, Normark S, Hultgren SJ. Role of Escherichia coli curli operons in directing amyloid fiber formation. Science. 2002;295(5556): 851-5.

28. Schramm FD, Schroeder K, Alvelid J, Testa I, Jonas $K$. Growth-driven displacement of protein aggregates along the cell length ensures partitioning to both daughter cells in Caulobacter crescentus. Mol Microbiol. 2019;111(6):1430-1448.

29. Govers SK, Mortier J, Adam A, Aertsen A. Protein aggregates encode epigenetic memory of stressful encounters in individual Escherichia coli cells. PLoS Biol. 2018;16(8):e2003853.

30. Gupta A, Lloyd-Price J, Neeli-Venkata R, Oliveira $S M$, Ribeiro $A S$. In vivo kinetics of segregation and polar retention of MS2-GFP-RNA complexes in Escherichia coli. Biophys J. 2014;106(9):192837.

31. Lindner AB, Madden R, Demarez A, Stewart EJ, Taddei $F$. Asymmetric segregation of protein aggregates is associated with cellular aging and rejuvenation. Proc Natl Acad Sci U S A. 2008;105(8):3076-81.

32. Schramm DF. Stress response regulation and protein aggregate inheritance in Caulobacter crescentus. Stockholm: "Vivi Täckholmsalenpress", 2019; 81 p.

33. Vedel S, Nunns H, Košmrlj A, Semsey S, Trusina A. Asymmetric damage segregation constitutes an emergent population-level stress response. Cell Syst. 2016;3(2):187-198.

34. Wang X, Cole CG, DuPai CD, Davies BW. Protein Aggregation is Associated with Acinetobacter baumannii Desiccation Tolerance. Microorganisms. 2020;8(3):343.

35. Govers SK, Aertsen A. Impact of high hydrostatic pressure processing on individual cellular resuscitation times and protein aggregates in Escherichia coli. Int J Food Microbiol. 2015;213:17-23.

36. Gayán E, Govers SK, Aertsen A. Impact of high hydrostatic pressure on bacterial proteostasis. Biophys Chem. 2017;231:3-9.
37. Hartl FU, Hayer-Hartl M. Converging concepts of protein folding in vitro and in vivo. Nat Struct Mol Biol. 2009;16(6):574-81.

38. Borgqvist J, Welkenhuysen N, Cvijovic M. Synergistic effects of repair, resilience and retention of damage determine the conditions for replicative ageing. Sci Rep. 2020;10(1):1556.

39. Butterfield SM, Lashuel HA. Amyloidogenic proteinmembrane interactions: mechanistic insight from model systems. Angew Chem Int Ed Engl. 2010; 49(33):5628-54.

40. Malishev R, Abbasi R, Jelinek R, Chai L. Bacterial Model Membranes Reshape Fibrillation of a Functional Amyloid Protein. Biochemistry. 2018;57(35): 5230-5238.

41. Fernández C, Núñez-Ramírez R, Jiménez M, Rivas $G$, Giraldo $R$. RepA-WH1, the agent of an amyloid proteinopathy in bacteria, builds oligomeric pores through lipid vesicles. Sci Rep. 2016;6:23144.

42. Molina-García L, Moreno-Del Álamo M, Botias $P$, Martín-Moldes Z, Fernández M, Sánchez-Gorostiaga A, Alonso-Del Valle A, Nogales J, GarcíaCantalejo J, Giraldo R. Outlining Core Pathways of Amyloid Toxicity in Bacteria with the RepAWH1 Prionoid. Front Microbiol. 2017;8:539.

43. Cámara-Almirón J, Caro-Astorga J, de Vicente A, Romero $D$. Beyond the expected: the structural and functional diversity of bacterial amyloids. Crit Rev Microbiol. 2018;44(6):653-666.

44. Rouse SL, Hawthorne WJ, Berry JL, Chorev DS, Ionescu SA, Lambert S, Stylianou F, Ewert W, Mackie U, Morgan RML, Otzen D, Herbst FA, Nielsen PH, Dueholm M, Bayley H, Robinson CV, Hare S, Matthews $S$. A new class of hybrid secretion system is employed in Pseudomonas amyloid biogenesis. Nat Commun. 2017;8(1):263.

45. Van Gerven N, Klein RD, Hultgren SJ, Remaut $H$. Bacterial amyloid formation: structural insights into curli biogensis. Trends Microbiol. 2015;23(11):693706.

46. Wang $Y, P u J, A n B$, Lu TK, Zhong $C$. Emerging Paradigms for Synthetic Design of Functional Amyloids. J Mol Biol. 2018;430(20):3720-34.

47. Barran-Berdon AL, Ocampo $S$, Haider M, MoralesAparicio J, Ottenberg G, Kendall A, Yarmola E, 
Mishra S, Long JR, Hagen SJ, Stubbs G, Brady LJ. Enhanced purification coupled with biophysical analyses shows cross- $\beta$ structure as a core building block for Streptococcus mutans functional amyloids. Sci Rep. 2020;10(1):5138.

48. Cámara-Almirón J, Navarro Y, Díaz-Martínez L, Magno-Pérez-Bryan MC, Molina-Santiago C, Pearson JR, de Vicente A, Pérez-García A, Romero D. Dual functionality of the amyloid protein TasA in Bacillus physiology and fitness on the phylloplane. Nat Commun. 2020;11(1):1859.

49. Taglialegna A, Navarro $S$, Ventura S, Garnett $J A$, Matthews S, Penades JR, Lasa I, Valle J. Staphylococcal Bap Proteins Build Amyloid Scaffold Biofilm Matrices in Response to Environmental Signals. PLoS Pathog. 2016;12(6): 1005711.

50. Alteri CJ, Xicohténcatl-Cortes J, Hess S, CaballeroOlín G, Girón JA, Friedman RL. Mycobacterium tuberculosis produces pili during human infection. Proc Natl Acad Sci U S A. 2007;104(12):5145-50.

51. Oh J, Kim JG, Jeon E, Yoo CH, Moon JS, Rhee S, Hwang I. Amyloidogenesis of type III-dependent harpins from plant pathogenic bacteria. J Biol Chem. 2007;282(18):13601-9.

52. Sampson TR, Challis C, Jain N, Moiseyenko A, Ladinsky MS, Shastri GG, Thron T, Needham BD, Horvath I, Debelius JW, Janssen S, Knight R, Wittung-Stafshede P, Gradinaru V, Chapman M, Mazmanian $S K$. A gut bacterial amyloid promotes $\alpha$-synuclein aggregation and motor impairment in mice. Elife. 2020;9:e53111.

53. Friedland RP, McMillan JD, Kurlawala Z. What are the molecular mechanisms by which functional bacterial amyloids influence amyloid beta deposition and neuroinflammation in neurodegenerative disorders? Int J Mol Sci. 2020;21(5):1652.

54. Mortier J, Tadesse W, Govers SK, Aertsen A. Stressinduced protein aggregates shape population heterogeneity in bacteria. Curr Genet. 2019;65(4):865-869.

55. Iglesias V, de Groot NS, Ventura S. Computational analysis of candidate prion-like proteins in bacteria and their role. Front Microbiol. 2015;6:1123.

56. Pallarès I, Ventura $S$. The transcription terminator rho: a first bacterial prion. Trends Microbiol. 2017;25(6):434-437.
57. Shahnawaz M, Park KW, Mukherjee A, Diaz-Espinoza $R$, Soto $C$. Prion-like characteristics of the bacterial protein Microcin E492. Sci Rep. 2017;7:45720.

58. Liebman SW, Chernoff YO. Prions in yeast. Genetics. 2012;191(4):1041-72.

59. Scheckel C, Aguzzi A. Prions, prionoids and protein misfolding disorders. Nat Rev Genet. 2018;19(7):405-418.

\section{Білкові агрегати як носії негенетичної пам'яті у бактерій після стресу}

О. Є. Кухаренко, В. О. Терзова, Г. В. Зубова

Агрегування білків пов'язане з утворенням олігомерів і комплексів, що призводять до порушень клітинних процесів. Утворення білкових агрегатів асоціюється 3 патологіями та старінням у еукаріотів, тоді як у бактерій цей процес викликає різкі зміни швидкості росту, стійкості до стресу і вірулентності.Проте, за певних обставин ці агрегати відіграють функціональнуроль. Фактори навколишнього середовища та внутрішньоклітинні фактори посилюють пошкодження білка за рахунок його скупчення, тим не менш, за сублетальних доз протеотоксичних стресових факторів навколишнього середовища, білкові агрегати можуть покращувати стійкість клітин та зберігати механізмиепігенетичної пам'яті про дію попередніх стресорів протягом декількох поколінь. Наведені дані про агреговані білки, що мають ознаки негенетичного (епігенетичного) спадкування, показують, що успадкування на основі білка відомо в усіх трьох царствах живих організмів. У цьому огляді увагу акцентовано на білкових агрегатах як носіях негенетичної пам'яті бактерій.

К л юч о в і с л о в а: білкові агрегати, бактерії, стрес, епігенетичне спадкування.

\section{Белковые агрегаты как носители негенетической памяти у бактерий после стресса}

О. Е. Кухаренко, В. А. Терзова, А. В. Зубова

Агрегация белка связана с образованием олигомеров и агрегатов, что приводит к нарушениям клеточных процессов. Образование белковых агрегатов связано с 
патологиями и старением у эукариот, тогда как у бактерий агрегация вызывает резкие изменения скорости роста, устойчивости к стрессу и вирулентности, но в определенних обстоятельствах эти агрегаты играют функциональную роль. Факторы окружающей среды и внутриклеточные факторы усиливают повреждение белка за счет агрегации, тем не менее, при сублетальных дозах протеотоксических стрессовых факторов окружающей среды белковые агрегаты могут улучшать устойчивость клеткок и сохранять механизмы негенетической памятио предыдущих стрессорах в течение нескольких поколений. Приведенные в обзоре данные показывают, что агрегированные белки обладают признаками негенетического наследования, и этоявление распространено во всех трех царствах живых организмов. В этом обзоре основное внимание уделяется белковым агрегатам как носителям негенетической памяти у бактерий.

Кл юч в в е с л о в а: белковые агрегаты, бактерии, стресс, эпигенетическое наследование

Received 02.06.2020 